\title{
Intermittent Fasting, Nutritional Supplementation, and Resistance Training as Strategy for Body Weight Loss: An Update
}

\author{
Ayuno Intermitente, Suplementación Nutricional y Entrenamiento de Resistencia \\ como Estrategia para la Pérdida de Peso Corporal: Una Actualización
}

\author{
Cristian Sandoval' ; Francisca Villagrán²; Sybella Santibañez ${ }^{3}$ \& Claudia Vargas $^{4}$
}

SANDOVAL, C.; VILLAGRÁN, F.; SANTIBAÑEZ, S. \& VARGAS, C. Intermittent fasting, nutritional supplementation, and resistance training as strategy for body weight loss. An update. Int. J. Morphol., 39(1):172-178, 2021.

SUMMARY: Obesity is a multifactorial disease, affecting, along with overweight, over a third of the adult population worldwide. Although weight control is beneficial, the problem of poor compliance in weight loss programs is well known. Therefore, different strategies have been described against overweight. Among them, strategies such as intermittent fasting, time-restricted feeding and Ramadan fasting have been identified. In recent years, other strategies such as nutritional supplementation have gained significance on weight loss, mainly due to focusing on body composition is even more important than overall weight. In this sense, consumption of nutritional supplements in athletes and sedentary people have shown beneficial effects. Also, supplement intake such, protein, creatine and beta-hydroxy-beta-methylbutyrate; combined with resistance training resulted in an increased body weight and fat-free mass. So, although resistance training increases muscle mass and resting metabolic rate, it does not result in weight loss without caloric restriction. Despite this, it seems even without caloric restriction, has favorable effect on body composition because it decreases fat mass, including abdominal fat. According to the evidence, our review suggests that a strategy for improving body composition might be to use a mixed protocol that includes intermittent fasting, nutritional supplementation intake, and resistance training.

KEY WORDS: Body weight; Fasting; Resistance training; Supplements.

\section{INTRODUCTION}

The current obesity epidemic in developed countries is staggering in terms of its magnitude and public health impact. Prevalence estimates of overweight and obesity reported by the World Health Organization in 2014 showed that $39 \%$ (1.9 million) of adults aged 18 and over were overweight, and of these $13 \%$ (600 million) were obese (World Health Organization, 2016).

Obesity is a multifactorial disease, affecting, along with overweight, over a third of the adult population worldwide (Chooi et al., 2019) with an increasing prevalence (NCD Risk Factor Collaboration, 2017). It is defined as abnormal or excessive fat accumulation that presents a risk to health. The metabolic disorders associated with obesity such as type 2 diabetes, hypertension, and hyperlipidemia are known signs of what is now described as the metabolic syndrome (Spiegelman \& Flier, 2001; Ezzati, 2004;
Swinburn et al., 2004; Pan et al., 2014). Because of its significant effects on health, medical costs, and mortality, obesity has become a public health concern.

Excess adiposity is an established risk factor for allcause mortality and a public health burden (Tobias \& Hu, 2018; Jaacks et al., 2019). Lifestyle intervention is the firstline therapy to treat obesity and prevent the associated comorbidity, even if its success is often limited (Yannakoulia et al., 2019). Although weight control is beneficial, the problem of poor compliance in weight loss programs is well known (Dansinger et al., 2005). Even where reduced weights are maintained, many of the benefits achieved during weight loss, including improvements in insulin sensitivity, may be attenuated due to non-compliance or adaptation (Henry et al., 1985). Sustainable and effective energy restriction strategies are thus required.

\footnotetext{
${ }^{1}$ Department of Preclinical Sciences, Faculty of Medicine, Universidad de la Frontera, Temuco, Chile.

${ }^{2}$ Doctoral Program in Morphological Sciences, Faculty of Medicine, Universidad de la Frontera, Temuco, Chile.

${ }^{3}$ Undergraduate Program of Nutrition and Diet, Faculty of Sciences, Universidad Mayor, Temuco, Chile.

${ }^{4}$ Department of Physical Education, Sports and Recreation, Faculty of Education, Universidad de La Frontera, Temuco, Chile.

FUNDING: DIUFRO NDI19-0004 and DIUFRO NºDI20-0001 Projects, Universidad de La Frontera, Chile.
} 
Intermittent fasting. As obesity rates climb, there is increasing focus on dietary interventions, which achieve initial but often unsustained weight loss (Howard et al., 2006). There is recent interest in the use of fasting for the treatment of obesity (Collier, 2013a,b) and diabetes (Fung, 2016; Mattson et al., 2017). Current guidelines recommend continuous energy restriction (CER) along with a comprehensive lifestyle intervention to obesity treatment. However, there has been increased interest in identifying alternative dietary weight loss strategies that involve restricting energy intake to certain periods of the day or prolonging the fasting interval between meals (i.e., intermittent energy restriction, IER). These strategies include intermittent fasting (IF; > $60 \%$ energy restriction on 2-3 days per week, or on alternate days) and time-restricted feeding (TRF; limiting the daily period of food intake to 8$10 \mathrm{~h}$ or less on most days of the week) (Rynders et al., 2019). IF covers a broad class of interventions that alternate periods of eating and extended fasting, where it is associated with substantial weight loss in short periods of time, during around 8 to 12 weeks. IF interventions include periodic 24-hour fasts, intermittent energy restriction (e.g., the 5:2 diet), and time-restricted feeding that includes Ramadan fasting (RF). On in vivo models, IF has been found to improve cardiometabolic health, reduce cancer incidence, reduce the rate of tumor growth, regenerate organs by increasing stem cell production, and increase lifespan (Mattson et al.; Harvie $\&$ Howell, 2017). Meanwhile in humans, data on IF is limited but suggest that it decreases body weight, insulin levels, blood pressure, inflammation, and appetite, and that it improves insulin sensitivity and lipid profiles (Mattson et al.; Antoni et al., 2017; Tinsley \& Horne, 2018).

There is increasing interest in the use of IER for weight management and thus disease risk (Johnstone, 2014; Seimon et al., 2015). In effect, clinical trials show IER can lead to significant reductions in body weight and adiposity either comparable to or greater than CER (Harvie et al., 2010, 2013; Varady et al., 2013; Bhutani et al., 2013; Klempel et al., 2010; Davis et al., 2016). However, despite evidence suggesting IER might be beneficial for weight loss in some individuals with overweight or obesity (Harvie et al., 2010, 2013; Varady et al.; Bhutani et al.; Klempel et al.; Davis et $a l$.), there are concerns about the efficacy of IER and the potential overeating on unrestricted days that is seen in animal (Harvie \& Howell, 2016) and some human models (Laessle et al., 1996).

In relation to the body weight, TRF has shown to facilitate weight loss through the meal-timing interventions by decreasing appetite rather than by increasing energy expenditure, where TRF showed lowered values of ghrelin and leptin (Ravussin et al., 2019). In this sense, TRF has shown to increase protein oxidation due to enhanced gluconeogenesis by extended fasting, meanwhile a decrease in nonprotein respiratory quotient (npRQ) appears to be indicative of enhanced fat loss by increasing fat oxidation due to the prolonged daily fasting period (Anton et al., 2018; Ravussin et al., 2019). Likewise, TRF has described a decrease in Fat Mass (FM) of resistance-trained males (Moro et al., 2016). Other kinds of IF, such IER or Intermittent Energy Restriction + Mediterranean Diet (IER+MED), have shown to generate a loss of body weight and FM, too (Harvie et al., 2011; Gnanou et al., 2015; Panizza et al., 2019). RF produced a weight loss through an increased energy expenditure (Lessan \& Ali, 2019).

The RF has shown metabolic benefits in previous studies (Fernando et al., 2019), which include greater circulating levels of high-density lipoprotein cholesterol (HDL-C), and reductions in blood pressure and circulating levels of low-density lipoprotein cholesterol (LDL-C), total cholesterol and glucose (Salim et al., 2013; Kul et al., 2014; Mazidi et al., 2015; Gill \& Panda, 2015; Chowdhury et al., 2016; Gabel et al., 2018; Sutton et al., 2018; Jamshed et al., 2019; Wilkinson et al., 2020). These changes were shown in healthy participants as well as in patients with chronic illnesses or disorders such as the metabolic syndrome. However, this kind of fasting has shown mixed results on people with type 2 diabetes mellitus, especially in terms of the profile of lipids in the circulation. Although beneficial in the case of many parameters including reduced FM (Alharbi et al., 2017) and improved glycaemic control (Khatib \& Shafagoj, 2004), several studies have shown unfavorable effects of RF on lipid profiles in people with diabetes (Comoglu et al., 2003; Yarahmadi et al., 2003; Khatib \& Shafagoj; Khaled et al., 2006), although neutral effects on lipid profile has also been described (Bener et al., 2006; Alharbi et al.). As such, more research into the effects of RF on people with diabetes is needed, and care needs to be taken when people with diabetes follow the RF.

Nutritional supplementation.Multiple factors involved in weight loss have been described. Most popular weight loss programs are able to reduce body weight within the first few weeks; despite the weight lost, a significant amount includes losses in both lean body mass (LBM) and FM, as well as changes in fluid status. The loss of LBM impedes sustainability by causing lowered resting energy expenditure, fatigue, declines in neuromuscular function, and increased injury risk (Ravussin et al., 1988; Tsai \& Wadden, 2005). Moreover, the metabolic decline that occurs after LBM loss results in a subsequent body fat overshoot, or a regain in FM (Dulloo et al., 2012), thereby producing unfavorable compounded changes in body composition. In an effort to offset this LBM loss, some supplements have been 
researched to augment weight loss or improve body composition, including but are not limited to: protein, creatine and beta-hydroxy-beta-methylbutyrate (HMB).

Achieving an adequate muscle mass is a key factor for sports performance as well as for attaining a good body image.Thus, muscle is increasingly being recognized as a key tissue for the maintenance of an adequate health status (Argilés et al., 2016). Here, the Resistance Training (RT) plays a pivotal role in development of muscular hypertrophy and as against sarcopenia; where it has been well documented that RT enhances skeletal muscle hypertrophy, and greater RT volume is associated with higher muscle protein turnover (Burd et al., 2010). According to numerous studies, postexercise supplements, particularly whey protein, acutely stimulates significant increases in post-exercise muscle protein synthesis (Atherton \& Smith, 2012).

Multi-ingredient performance supplements (MIPS) intended for consumption in close proximity to RT are extremely popular among young males (Massad et al., 1995; Young \& Stephens, 2009) and athletes (Erdman et al., 2007). The composition of MIPS varies widely, but the principle ingredients generally include proteins, creatine monohydrate, HMB, caffeine, beta alanine, the branched chain amino acids (BCAAs) such as leucine, isoleucine, and valine, as well as L-citrulline, and L-arginine. Most of these ingredients have shown to exert ergogenic effects during aerobic and anaerobic exercise or facilitate muscle hypertrophy over the course of a RT period in untrained participants (Artioli et al., 2010; Sale et al., 2010; Fukuda et al., 2010; Smith et al., 2010).

Protein has been widely used for athletes, highly active and sedentary people as a muscle growth and performance-enhancing product, where high-protein and lowcarbohydrate diets are applied for weight-loss purposes. It plays a critical role in countless physiological processes in the body. The current Recommended Dietary Allowance (RDA) for healthy individuals is $0.8 \mathrm{~g} / \mathrm{kg} /$ day (Kato et al., 2016). However, protein intake of at least $1.4-1.6 \mathrm{~g} / \mathrm{kg} / \mathrm{day}$ (Jager et al., 2017) could be more suitable for active individuals attempting to optimize training adaptations.

Creatine is another type of sport supplements and is the most beneficial ones, based upon years of scientific research (Campbell et al., 2007). Creatine supplementation increases total creatine as well as phosphocreatine stores in the muscle allowing to increase LBM (Willoughby \& Rosene, 2001; Kerksick et al., 2009), enhances exercise performance (Kreider, 2003) and increases training volume (Volek et al., 1997) in individuals engaged in RT. According to Ziegenfuss et al. (2002), creatine supplementation for as brief a period as 3 days has been shown to produce a significant increase in skeletal muscle volume and exercise performance. Furthermore, creatine supplementation combined with RT resulted in a $6.3 \%$ increase in body weight and fat-free mass (FFM) after a 12-week treatment period (Volek et al., 1999). However, not all investigations demonstrate a positive effect of creatine supplementation vis a vis body composition (Tipton \& Wolfe, 2004; Chilibeck et al., 2007; Tipton et al., 2007; Sakkas et al., 2009; Bemben et al., 2010).

The HMB shows anabolic and anti-catabolic actions in skeletal muscle (Wilkinson et al., 2013). However, studies examining HMB supplementation and RT have reported mixed results (Jowko et al., 2001; O'Connor \& Crowe, 2007). Recently, two studies using HMB in its free-acid form (HMB-FA) have shown exceptional improvements in LBM in resistance-trained men (Wilson et al., 2014; Lowery et $a l .$, 2016). Lowery et al. combined HMB-FA with ATP, whereas Wilson et al. supplemented HMB-FA alone. In conjunction with 12 weeks of periodical resistance training, participants increased LBM by $\sim 8.5 \mathrm{~kg}$ and $\sim 7.5 \mathrm{~kg}$, respectively.

Resistance training. Resistance or strength training is known to increase LBM and muscle strength (Deschenes \& Kraemer, 2002). However, although RT increases muscle mass, it does not result in weight loss without caloric restriction. But, RT even without caloric restriction, has favorable effect on body composition because it decreases FM including abdominal fat (Hunter et al., 2002; Cuff et al., 2003; Tresierras \& Balady, 2009). On this sense, the most commonly cited reason for the reduction of FM and body weight by RT is that resting metabolic rate (RMR) theoretically increases as LBM increases (Pratley et al., 1994; Dolezal \& Potteiger, 1998; Lemmer et al., 2001), resulting in a steady state increase in total energy expenditure and a corresponding negative shift in energy balance.

The contribution of resistance exercise to resting metabolic rate (RMR) through increased (FFM), elevated catecholamine levels, and excess post-exercise oxygen consumption (EPOC) has been established. Thus, through increasing RMR, resistance exercise may contribute to increased daily energy expenditure, net negative energy balance, and therefore increased weight loss (Jeffrey, 2002).

Fat oxidation occurs during RT when fat is broken down to obtain energy, where it types of exercise can cause an increase in fat oxidation, both acutely and chronically (Melby et al., 1993; Pratley et al.), through the increased use of carbohydrate (CHO) to replenish glycogen stores in the muscles (Melby et al.). Glycogen is the stored form of 
glucose that supplies the muscles with energy during exercise. Because $\mathrm{CHO}$ is being stored at a greater rate after exercise than before exercise, the body must utilize fat as a primary source for energy. Increases in fat oxidation may also be attributed to an increase in catecholamines, which results in an increased rate of lipolysis or fat oxidation (Pratley et al.).

Focusing on body composition is essential because even more important than overall weight loss is sustainably losing FM while maintaining LBM. The strategies to preserve LBM during dietary-induced weight loss in patients with obesity include a combination of RT and a sufficient intake of high-quality protein (Verreijen et al., 2015).

\section{CONCLUSIONS}

This review highlights the studies that explain intermittent fasting, nutritional supplementation, and RT as a strategy for body weight loss. Currently, any of these methods have been used for weight loss. However, focusing on body composition instead of than weight loss should be the primary aim of these protocols. Despite all the advances that have been made to evaluate LBM, FFM, FM or body composition, the relation between different types of fasting, nutritional supplementation and RT have not yet been satisfactorily resolved. In this way, future studies should clarify more efficiently the relationship between these variables to understand the weight loss process on active and healthy people.

SANDOVAL, C.; VILLAGRÁN, F.; SANTIBAÑEZ, S. \& VARGAS, C. Ayuno intermitente, suplementación nutricional y entrenamiento de resistencia como estrategia para la pérdida de peso corporal: Una actualización. Int. J. Morphol., 39(1):172-178, 2021.

RESUMEN: La obesidad es una enfermedad multifactorial, afectando junto al sobrepeso, un tercio de la población mundial adulta. Aunque el control del peso es beneficioso, el problema del mal cumplimiento en los programas de pérdida de peso es bien conocido. Por lo que, distintas estrategias han sido descritas para combatirlo. Entre ellas, se han identificado estrategias como el ayuno intermitente, la alimentación con restricción de tiempo y el ayuno de Ramadán. En los últimos años, otras estrategias como la suplementación nutricional han ganado importancia en la pérdida de peso, principalmente debido a que centrarse en la composición corporal es incluso más importante que la pérdida de peso general. En este sentido, el consumo de suplementos nutricionales, como proteínas, creatina y beta-hidroxi-beta-metilbutirato; en atletas y personas sedentarias ha mostrado efectos beneficiosos. Asimismo, la ingesta de suplementos combinada con el ejercicio de resistencia resulta en un aumento del peso corporal y masa libre de grasa. Por lo que, aunque el ejercicio de resistencia produce un aumento en la masa mus- cular y la tasa metabólica en reposo, este no provoca pérdida de peso sin restricción calórica. Pese a ello, tiene un efecto favorable sobre la composición corporal porque disminuye la masa grasa, incluida la grasa abdominal. Nuestra revisión sugiere que una estrategia para mejorar la composición corporal podría ser la utilización de un protocolo mixto que incluya el ayuno intermitente, el consumo de suplementos nutricionales y el entrenamiento de resistencia.

PALABRAS CLAVE: Peso corporal; Ayuno; Entrenamiento de Resistencia; Suplementos.

\section{REFERENCES}

Alharbi, T. J.; Wong, J.; Markovic, T.; Yue, D.; Wu, T.; Brooks, B.; Hetherington, J.; Seimon, R.; Gibson, A. A.; Toth, K.; et al. Brief report: Ramadan as a model of intermittent fasting: Effects on body composition, metabolic parameters, gut hormones and appetite in adults with and without type 2 diabetes mellitus. Obes. Med., 6:15-7, 2017.

Anton, S. D.; Moehl, K.; Donahoo, W. T.; Marosi, K.; Lee, S.; Mainousai, A. G.; Leeiwenburgh, C. \& Mattson, M. P. Flipping the metabolic switch: understanding and applying the health benefits of fasting. Obesity (Silver Spring), 26(2):254-68, 2018.

Antoni, R.; Johnston, K. L.; Collins, A. L. \& Robertson, M. D. Effects of intermittent fasting on glucose and lipid metabolism. Proc. Nutr. Soc., 76(3):361-8, 2017.

Argilés, J. M.; Campos, N.; Lopez-Pedrosa, J. M.; Rueda, R. \& RodriguezMañas, L. Skeletal Muscle Regulates Metabolism via Interorgan Crosstalk: Roles in Health and Disease. J. Am. Med. Dir. Assoc., 17(9):789-96, 2016.

Artioli, G. G.; Gualano, B.; Smith, A.; Stout, J. \& Lancha, A. H. Role of beta-alanine supplementation on muscle carnosine and exercise performance. Med. Sci. Sports Exerc., 42(6):1162-73, 2010.

Atherton, P. J. \& Smith, K. Muscle protein synthesis in response to nutrition and exercise. J. Physiol., 590(Pt. 5):1049-57, 2012.

Bemben, M. G.; Witten, M. S.; Carter, J. M.; Eliot, K. A.; Knehans, A. W. $\&$ Bemben, D. A. The effects of supplementation with creatine and protein on muscle strength following a traditional resistance training program in middle- aged and older men. J. Nutr. Health Aging, 14(2):155-9, 2010.

Bener, A.; Hamad, A.; Fares, A.; Al-Sayed, H. M. \& Al-Suwaidi, J. Is there any effect of Ramadan fasting on stroke incidence? Singapore Med. J., 47(5):404-8, 2006.

Bhutani, S.; Klempel, M. C.; Kroeger, C. M.; Aggour, E.; Calvo, Y.; Trepanowski, J. F.; Hoddy, K. K. \& Varady, K. A. Effect of exercising while fasting on eating behaviors and food intake. J. Int. Soc. Sports Nutr., 10(1):50, 2013.

Burd, N. A.; Holwerda, A. M.; Selby, K. C.; West, D. W.; Staples, A. W.; Cain, N. E.; Cashaback, J. G.; Potvin, J. R.; Baker, S. K. \& Phillips, S. $\mathrm{M}$. Resistance exercise volume affects myofibrillar protein synthesis and anabolic signalling molecule phosphorylation in young men. $J$. Physiol., 588(Pt. 16):3119-30, 2010.

Campbell, B.; Kreider, R. B.; Ziegenfuss, T.; La Bounty, P.; Roberts, M.; Burke, D.; Landis, J.; Lopez, H. \& Antonio, J. International society of sports nutrition position stand: protein and exercise. J. Int. Soc. Sports Nutr., 4:8, 2007.

Chilibeck, P. D.; Magnus, C. \& Anderson, M. Effect of in-season creatine supplementation on body composition and performance in rugby union football players. Appl. Physiol. Nutr. Metab., 32(6):1052-7, 2007.

Chooi, Y. C.; Ding, C. \& Magkos, F. The epidemiology of obesity. Metab. Clin. Exp., 92:6-10, 2019. 
Chowdhury, E. A.; Richardson, J. D.; Holman, G. D.; Tsintzas, K.; Thompson, D. \& Betts, J. A. The causal role of breakfast in energy balance and health: a randomized controlled trial in obese adults. Am. J. Clin. Nutr., 103(3):747-56, 2016.

Collier, R. Intermittent fasting: the next big weight loss fad. CMAJ, 185(8):E321-2, 2013b.

Collier, R. Intermittent fasting: the science of going without. CMAJ, 185(9):E363-4, 2013a.

Comoglu, S.; Temizhan, A.; Pesinci, E.; Tandogan, I. \& Ozbakir, S. Effects of Ramadan Fasting on Stroke. Turk J. Med. Sci., 33(4):237-41, 2003.

Cuff, D. J.; Meneilly, G. S.; Martin, A.; Ignaszewski, A.; Tildesley, H. D. \& Frohlich, J. J. Effective exercise modality to reduce insulin resistance in women with type 2 diabetes. Diabetes Care, 26(11):2977-82, 2003.

Dansinger, M. L.; Gleason, J. A.; Griffith, J. L.; Selker, H. P. \& Schaefer, E. J. Comparison of the Atkins, Ornish, Weight Watchers, and Zone diets for weight loss and heart disease risk reduction: a randomized trial. JAMA, 293(1):43-53, 2005.

Davis, C. S.; Clarke, R. E.; Coulter, S. N.; Rounsefell, K. N.; Walker, R. E.; Rauch, C. E.; Huggins, C. E. \& Ryan, L. Intermittent energy restriction and weight loss: A systematic review. Eur. J. Clin. Nutr., 70(3):292-9, 2016.

Deschenes, M. R. \& Kraemer, W. J. Performance and physiologic adaptations to resistance training. Am. J. Phys. Med. Rehabil., 81(11Suppl.):S3-16, 2002.

Dolezal, B. A. \& Potteiger, J. A. Concurrent resistance and endurance training influence basal metabolic rate in nondieting individuals. $J$. Appl. Physiol., 85(2):695-700, 1998.

Dulloo, A.; Jacquet, J. \& Montani, J. P. How dieting makes some fatter: From a perspective of human body composition autoregulation. Proc. Nutr. Soc., 71(3):379-89, 2012.

Erdman, K. A.; Fung, T. S.; Doyle-Baker, P. K.; Verhoef, M. J. \& Reimer, R. A. Dietary supplementation of high-performance Canadian athletes by age and gender. Clin. J. Sport Med., 17(6):458-64, 2007.

Ezzati, M. Comparative Quantification of Health Risks. Global and Regional Burden of Disease Attributable to Selected Major Risk Factors. Ginebra, Organización Mundial de la Salud, 2004.

Fernando, H. A.; Zibellini, J.; Harris, R. A.; Seimon, R. V. \& Sainsbury, A. Effect of Ramadan fasting on weight and body composition in healthy non-athlete adults: a systematic review and metaanalysis. Nutrients, 11(2):478, 2019.

Fukuda, D. H.; Smith, A. E.; Kendall, K. L. \& Stout, J. R. The possible combinatory effects of acute consumption of caffeine, creatine, and amino acids on the improvement of anaerobic running performance in humans. Nutr. Res., 30(9):607-14, 2010.

Fung, J. The Obesity Code. Unlocking the Secrets of Weight Loss. Vancouver, Greystone Books, 2016.

Gabel, K.; Hoddy, K. K.; Haggerty, N.; Song, J.; Kroeger, C. M.; Trepanowski, J. F.; Panda, S. \&Varady, K. A. Effects of 8-hour time restricted feeding on body weight and metabolic disease risk factors in obese adults: A pilot study. Nutr. Healthy Aging, 4(4):345-53, 2018.

Gill, S. \& Panda, S. A smartphone app reveals erratic diurnal eating patterns in humans that can be modulated for health benefits. Cell Metab., 22(5):789-98, 2015.

Gnanou, J. V.; Caszo, B. A.; Khalil, K. M.; Abdullah, S. L.; Knight, V. F. \& Bidin, M. Z. Effects of Ramadan fasting on glucose homeostasis and adiponectin levels in healthy adult males. J. Diabetes Metab. Disord., 14:55, 2015.

Harvie, M. \& Howell, A. Potential benefits and harms of intermittent energy restriction and intermittent fasting amongst obese, overweight and normal weight subjects-A narrative review of human and animal evidence. Behav. Sci., 7(1):4, 2017.

Harvie, M. N. \& Howell, T. Could intermittent energy restriction and intermittent fasting reduce rates of cancer in obese, overweight, and normal-weight subjects? A summary of evidence. $A d v$. Nutr, 7(4):690-705, 2016.

Harvie, M. N.; Pegington, M.; Mattson, M. P.; Frystyk, J.; Dillon, B.; Evans, G.; Cuzick, J.; Jebb, S. A.; Martin, B.; Cutler, R. G.; et al. The effects of intermittent or continuous energy restriction on weight loss and metabolic disease risk markers: a randomized trial in young overweight women. Int. J. Obes.,35(5):714-27, 2011.

Harvie, M. N.; Pegington, M.; Mattson, M. P.; Frystyk, J.; Dillon, B.; Evans, G.; Cuzick, J.; Jebb, S. A.; Martin, B.; Cutler, R. G.; et al. The effects of intermittent or continuous energy restriction on weight loss and metabolic disease risk markers: A randomized trial in young overweight women. Int. J. Obes., 35(5):714-27, 2010.

Harvie, M.; Wright, C.; Pegington, M.; McMullan, D.; Mitchell, E.; Martin, B.; Cutler, R. G.; Evans, G.; Whiteside, S.; Maudsley, S.; et $a l$. The effect of intermittent energy and carbohydrate restriction v. Daily energy restriction on weight loss and metabolic disease risk markers in overweight women. Br. J. Nutr., 110(8):1534-47, 2013.

Henry, R. R.; Scheaffer, L. \& Olefsky, J. M. Glycemic effects of intensive caloric restriction and isocaloric refeeding in noninsulin-dependent diabetes mellitus. J. Clin. Endocrinol. Metab., 61(5):917-25, 1985.

Howard, B. V.; Manson, J. E.; Stefanick, M. L.; Beresford, S. A.; Frank, G.; Jones, B.; Rodabough, R. J.; Snetselaar, L.; Thomson, C.; Tinker, L.; et al. Low-fat dietary pattern and weight change over 7 years: the Women's Health Initiative Dietary Modification Trial. JAMA, 295(1):39-49, 2006

Hunter, G. R.; Bryan, D. R.; Wetzstein, C. J.; Zuckerman, P. A. \& Bamman, M. M. Resistance training and intra-abdominal adipose tissue in older men and women. Med. Sci. Sports Exerc., 34(6):1023$8,2002$.

Jaacks, L. M.; Vandevijvere, S.; Pan, A.; McGowan, C. J.; Wallace, C.; Imamura, F.; Mozaffarian, D.; Swinburn, B. \& Ezzati, M. The obesity transition: stages of the global epidemic. Lancet Diabetes Endocrinol., 7(3):231-40, 2019.

Jager, R.; Kerksick, C. M.; Campbell, B. I.; Cribb, P. J.; Wells, S. D.; Skwiat, T. M.; Purpura, M.; Ziegenfuss, T. N.; Ferrando, A. A.; Arent, S. M.; et al. International society of sports nutrition position stand: protein and exercise. J. Int. Soc. Sports Nutr., 14:20, 2017.

Jamshed, H.; Beyl, R. A.; Della Manna, D. L.; Yang, E. S.; Ravussin, E. \& Peterson, C. M. Early time-restricted feeding improves 24-hour glucose levels and affects markers of the circadian clock, aging, and autophagy in humans. Nutrients, 11(6):1234, 2019.

Jeffrey, A. The role of resistance exercise in weight loss. Strength Cond. J., 24(1):65-9, 2002.

Johnstone, A. Fasting for weight loss: An effective strategy or latest dieting trend? Int. J. Obes. (Lond), 39(5):727-33, 2014.

Jowko, E.; Ostaszewski, P.; Jank, M.; Sacharuk, J.; Zieniewicz, A.; Wilczak, J. \& Nissen, S. Creatine and beta-hydroxy-betamethylbutyrate (HMB) additively increase lean body mass and muscle strength during a weight-training program. Nutrition, 17(78):558-66, 2001

Kato, H.; Suzuki, K.; Bannai, M. \& Moore, D. R. Protein requirements are elevated in endurance athletes after exercise as determined by the indicator amino acid oxidation method. PLoS One, 11(6): $\mathrm{e} 0157406,2016$.

Kerksick, C. M.; Wilborn, C. D.; Campbell, W. I.; Harvey, T. M.; Marcello, B. M.; Roberts, M. D.; Parker, A. G.; Byars, A. G.; Greenwood, L. D.; Almada, A. L.; et al. The effects of creatine monohydrate supplementation with and without D-pinitol on resistance training adaptations. J. Strength Cond. Res., 23(9):267382, 2009.

Khaled, B. M.; Bendahmane, M. \& Belbraouet, S. Ramadan fasting induces modifications of certain serum components in obese women with type 2 diabetes. Saudi Med. J., 27(1):23-6, 2006. 
Khatib, F. A. \& Shafagoj, Y. A. Metabolic alterations as a result of Ramadan fasting in non-insulin-dependent diabetes mellitus patients in relation to food intake. Saudi Med. J., 25(12):1858-63, 2004.

Klempel, M. C.; Bhutani, S.; Fitzgibbon, M.; Freels, S. \& Varady, K. A. Dietary and physical activity adaptations to alternate day modified fasting: Implications for optimal weight loss. Nutr. J., 9:35, 2010.

Kreider, R. B. Effects of creatine supplementation on performance and training adaptations. Mol. Cell. Biochem., 244(1-2):89-94, 2003.

Kul, S.; Savas, E.; Ozturk, Z.A. \& Karadag, G. Does Ramadan fasting alter body weight and blood lipids and fasting blood glucose in a healthy population? A meta-analysis. J. Relig. Health, 53(3):929$42,2014$.

Laessle, R. G.; Platte, P.; Schweiger, U. \& Pirke, K. M. Biological and psychological correlates of intermittent dieting behavior in young women. A model for bulimia nervosa. Physiol. Behav., 60(1):1-5, 1996.

Lemmer, J. T.; Ivey, F. M.; Ryan, A. S.; Martel, G. F.; Hurlbut, D. E.; Metter, J. E.; Fozard, J. L.; Fleg, J. L. \& Hurley, B. F. Effect of strength training on resting metabolic rate and physical activity: age and gender comparisons. Med. Sci. Sports Exerc., 33(4):53241, 2001

Lessan, N. \& Ali, T. Energy Metabolism and Intermittent Fasting: The Ramadan Perspective. Nutrients, 11(5):1192, 2019.

Lowery, R. P.; Joy, J. M.; Rathmacher, J. A.; Baier, S. M.; Fuller, J. C.; Shelley, M. C.; Jäger, R.; Purpura, M.; Wilson, S. M. \& Wilson, J. $\mathrm{M}$. Interaction of beta-hydroxy-beta-methylbutyrate free acid and adenosine triphosphate on muscle mass, strength, and power in resistance trained individuals. J. Strength Cond. Res., 30(7):184354, 2016.

Massad, S. J.; Shier, N. W.; Koceja, D. M. \& Ellis, N. T. High-school athletes and nutritional supplements - a study of knowledge and use. Int. J. Sport Nutr., 5(3):232-45, 1995.

Mattson, M. P.; Longo, V. D. \& Harvie, M. Impact of intermittent fasting on health and disease processes. Ageing Res. Rev., 39:46-58, 2017.

Mazidi, M.; Rezaie, P.; Chaudhri, O.; Karimi, E. \& Nematy, M. The effect of Ramadan fasting on cardiometabolic risk factors and anthropometrics parameters: A systematic review. Pak. J. Med. Sci., 31(5):1250-5, 2015.

Melby, C.; Scholl, C.; Edwards, G. \& Bullough, R. Effect of acute resistance exercise on post exercise energy expenditure and resting metabolic rate. J. Appl. Physiol., 75(4):1847-53, 1993.

Moro, T.; Tinsley, G.; Bianco, A.; Marcolin, G.; Pacelli, Q. F.; Battaglia, G.; Palma, A.; Gentil, P.; Neri, M. \& Paoli, A. Effects of eight weeks of time-restricted feeding (16/8) on basal metabolism, maximal strength, body composition, inflammation, and cardiovascular risk factors in resistance-trained males. J. Transl. Med., 14:290, 2016.

NCD Risk Factor Collaboration (NCD-RisC). Worldwide trends in body-mass index, underweight, overweight, and obesity from 1975 to 2016: a pooled analysis of 2416 population-based measurement studies in 128.9 million children, adolescents, and adults. Lancet, 390(10113):2627-42, 2017.

O'Connor, D. M. \& Crowe, M. J. Effects of six weeks of beta-hydroxybeta-methylbutyrate (HMB) and $\mathrm{HMB}$ /creatine supplementation on strength, power, and anthropometry of highly trained athletes. $J$. Strength Cond. Res., 21(2):419-23, 2007.

Pan, H.; Guo, J. \& Su, Z. Advances in understanding the interrelations between leptin resistance and obesity. Physiol. Behav., 130:157-69, 2014.

Panizza, C. E.; Lim, U.; Yonemori, K. M.; Cassel, K. D.; Wilkens, L. R.; Harvie, M. N.; Maskarinec, G.; Delp, E. J.; Lampe, J. W.; et al. Effects of intermittent energy restriction combined with a mediterranean diet on reducing visceral adiposity: A randomized active comparator pilot study. Nutrients, 11(6):1386, 2019.
Pratley, R.; Nicklas, B.; Rubin, M.; Miller, J.; Smith, A.; Smith, M.; Hurley, B. \& Goldberg, A. Strength training increases resting metabolic rate and norepinephrine levels in healthy 50- to 65-yr-old men. J. Appl. Physiol., 76(1):133-7, 1994.

Ravussin, E.; Beyl, R. A.; Poggiogalle, E.; Hsia, D. S. \& Peterson, C. M. Early time-restricted feeding reduces appetite and increases fat oxidation but does not affect energy expenditure in humans. Obesity (Silver Spring), 27(8):1244-54, 2019.

Ravussin, E.; Lillioja, S.; Knowler, W. C.; Christin, L.; Freymond, D.; Abbott, W. G.; Boyce, V.; Howard, B. V. \& Bogardus, C. Reduced rate of energy expenditure as a risk factor for body-weight gain. $N$. Engl. J. Med., 318(8):467-72, 1988.

Rynders, C. A.; Thomas, E. A.; Zaman, A.; Pan, Z.; Catenacci, V. A. \& Melanson, E. Effectiveness of intermittent fasting and timerestricted feeding compared to continuous energy restriction for weight loss. Nutrients, 11(10):2442, 2019.

Sakkas, G. K.; Mulligan, K.; Dasilva, M.; Doyle, J. W.; Khatami, H.; Schleich, T.; Kent- Braun, J. A. \& Schambelan, M. Creatine fails to augment the benefits from resistance training in patients with HIV infection: a randomized, double-blind, placebo-controlled study. PLoS One, 4(2):e4605, 2009.

Sale, C.; Saunders, B. \& Harris, R. C. Effect of beta-alanine supplementation on muscle carnosine concentrations and exercise performance. Amino Acids, 39(2):321-33, 2010.

Salim, I.; Suwaidi, A.I.; Ghadban, W.; Alkilani, H. \& Salam A. M. Impact of religious Ramadan fasting on cardiovascular disease: A systematic review of the literature. Curr. Med. Res. Opin., 29(4):343-54, 2013.

Seimon, R. V.; Roekenes, J. A.; Zibellini, J.; Zhu, B.; Gibson, A. A.; Hills, A. P.; Wood, R. E.; King, N. A.; Byrne, N. M. \& Sainsbury, A. Do intermittent diets provide physiological benefits over continuous diets for weight loss? A systematic review of clinical trials. Mol. Cell. Endocrinol., 418(Pt 2):153-72, 2015.

Smith, A. E.; Fukuda, D. H.; Kendall, K. L. \& Stout, J. R. The effects of a pre-workout supplement containing caffeine, creatine, and amino acids during three weeks of high-intensity exercise on aerobic and anaerobic performance. J. Int. Soc. Sport Nutr., 7:10, 2010.

Spiegelman, B. M. \& Flier, J. S. Obesity and the regulation of energy balance. Cell, 104(4):531-43, 2001.

Sutton, E. F.; Beyl, R.; Early, K. S.; Cefalu, W. T.; Ravussin, E. \& Peterson, C. M. Early time-restricted feeding improves insulin sensitivity, blood pressure, and oxidative stress even without weight loss in men with prediabetes. Cell Metab., 27(6):121221.e3, 2018.

Swinburn, B. A.; Caterson, I.; Seidell, J. C. \& James, W. P. T. Diet, nutrition and the prevention of excess weight gain and obesity. Public Health Nutr., 7(1A):123-46, 2004.

Tinsley, G. M. \& Horne, B. D. Intermittent fasting and cardiovascular disease: Current evidence and unresolved questions. Fut. Cardiol., 14(1):47-54, 2018.

Tipton, K. D. \& Wolfe, R. R. Protein and amino acids for athletes. $J$. Sports Sci., 22(1):65-79, 2004.

Tipton, K. D.; Elliott, T. A.; Cree, M. G.; Aarsland, A. A.; Sanford, A. P. \& Wolfe, R. R. Stimulation of net muscle protein synthesis by whey protein ingestion before and after exercise. Am. J. Physiol. Endocrinol. Metab., 292(1):E71-6, 2007.

Tobias, D. K. \& Hu, F. B. The association between BMI and mortality: implications for obesity prevention. Lancet Diabetes Endocrinol., 6(12):916-7, 2018.

Tresierras, M. A. \& Balady, G. J. Resistance training in the treatment of diabetes and obesity: mechanisms and outcomes. J. Cardiopulm. Rehabil. Prev., 29(2):67-75, 2009. 
Tsai, A. \& Wadden, T. A. Systematic review: An evaluation of major commercial weight loss programs in the United States. Ann. Intern. Med., 142(1):56-66, 2005.

Varady, K. A.; Bhutani, S.; Klempel, M. C.; Kroeger, C. M.; Trepanowski, J. F.; Haus, J. M.; Hoddy, K. K. \& Calvo, Y. Alternate day fasting for weight loss in normal weight and overweight subjects: A randomized controlled trial. Nutr. J., 12(1):146, 2013.

Verreijen, A. M.; Verlaan, S.; Engberink, M. F.; Swinkels, S.; de Vogelvan den Bosch, J. \& Weijs, P. J. A high whey protein-, leucine-, and vitamin D-enriched supplement preserves muscle mass during intentional weight loss in obese older adults: a double-blind randomized controlled trial. Am. J. Clin. Nutr., 101(2):279-86, 2015.

Volek, J. S.; Duncan, N. D.; Mazzetti, S. A.; Staron, R. S.; Putukian, M.; Gomez, A. L.; Pearson, D. R.; Fink, W. J. \& Kraemer, W. J. Performance and muscle fiber adaptations to creatine supplementation and heavy resistance training. Med. Sci. Sports Exerc., 31(8):1147-56, 1999.

Volek, J. S.; Kraemer, W. J.; Bush, J. A.; Boetes, M.; Incledon, T.; Clark, K. L. \& Lynch, J. M. Creatine supplementation enhances muscular performance during high-intensity resistance exercise. J. Am. Diet Assoc., 97(7):765-70, 1997.

Wilkinson, D. J.; Hossain, T.; Hill, D. S.; Phillips, B. E.; Crossland, H.; Williams, J.; Loughna, P.; Churchward-Venne, T. A.; Breen, L.; Phillips, S. M.; et al. Effects of leucine and its metabolite b-hydroxyb-methylbutyrate on human skeletal muscle protein metabolism. $J$. Physiol., 591(11):2911-23, 2013.

Wilkinson, M. J.; Manoogian, E. N. C.; Zadourian, A.; Lo, H.; Fakhouri, S.; Shoghi, A.; Wang, X.; Fleischer, J. G.; Navlakha, S.; Panda, S.; et $a l$. Ten-hour time-restricted eating reduces weight, blood pressure, and atherogenic lipids in patients with metabolic syndrome. Cell Metab., 31(1):92-104.e5, 2020.

Willoughby, D. S. \& Rosene, J. Effects of oral creatine and resistance training on myosin heavy chain expression. Med. Sci. Sports Exerc., 33(10):1674-81, 2001

Wilson, J. M.; Lowery, R. P.; Joy, J. M.; Andersen, J. C.; Wilson, S. M.; Stout, J. R.; Duncan, N.; Fuller, J. C.; Baier, S. M.; Naimo, M. A.; et $a l$. The effects of 12 weeks of beta-hydroxy-beta-methylbutyrate free acid supplementation on muscle mass, strength, and power in resistance-trained individuals: a randomized, double-blind, placebocontrolled study. Eur. J. Appl. Physiol., 114(6):1217-27, 2014.

World Health Organization. Overweight and Obesity Factsheet. Nueva York, World Health Organization, 2016.

Yannakoulia, M.; Poulimeneas, D.; Mamalaki, E. \& Anastasiou, C. A. Dietary modifications for weight loss and weight loss maintenance. Metab. Clin. Exp., 92:153-62, 2019.

Yarahmadi, S. H.; Larijani, B.; Bastanhagh, M. H.; Pajouhi, M.; Baradar, R. J.; Zahedi, F.; Zendehdel, K. \& Akrami, S. M. Metabolic and clinical effects of Ramadan fasting in patients with type II diabetes. $J$. Coll. Physicians Surg. Pak., 13(6):329-32, 2003.

Young, C. R. \& Stephens, M. B. Sports and nutritional supplement Use in USMC recruits: a pilot study. Mil. Med., 174(2):158-61, 2009.

Ziegenfuss, T. N.; Rogers, M.; Lowery, L.; Mullins, N.; Mendel, R.; Antonio, J. \& Lemon, P. Effect of creatine loading on anaerobic performance and skeletal muscle volume in NCAA Division I athletes. Nutrition, 18(5):397-402, 2002.

\author{
Corresponding author: \\ Dr. Claudia Vargas \\ Department of Physical Education Sports and Recreation \\ Faculty of Education \\ Universidad de La Frontera \\ 01145 Francisco Salazar Avenue \\ Temuco - CHILE
}

Email.claudia.vargas@ufrontera.cl

Received: 07-08-2020

Accepted: 10-11-2020 